\title{
Salvage felling in the Slovak Republic's forests during the last twenty years (1998-2017)
}

\author{
Andrej Kunca ${ }^{1 *}$, Milan Zúbrik ${ }^{1}$, Juraj Galko ${ }^{1}$, Jozef Vakula ${ }^{1}$, Roman Leontovyčํㅜㄹ \\ Bohdan Konôpka ${ }^{2,3}$, Christo Nikolov ${ }^{1}$, Andrej Gubka ${ }^{1}$, Valéria Longauerová ${ }^{2}$, \\ Miriam Malová 2 , Slavomír Rell ${ }^{1}$, Michal Lalík ${ }^{1,3}$
}

${ }^{1}$ National Forest Centre - Forest Research Institute Zvolen, Forest Protection Service Centre, Lesnícka 11, SK - 96901 Banská Stiavnica, Slovak Republic

${ }^{2}$ National Forest Centre - Forest Research Institute Zvolen, T. G. Masaryka 2175/22, SK - 96092 Zvolen, Slovak Republic ${ }^{3}$ Czech University of Life Sciences Prague, Faculty of Forestry and Wood Sciences, Kamýcká 129,

CZ - 16521 Praha 6 - Suchdol, Czech Republic

\begin{abstract}
Global climate change also influences the forest damaging agents occurrence and thus a forest health. Forest trees that are damaged by agents are in managed forests processed by salvage felling. The amount of an annual salvage felling represents the occurrence of a damaging agents occurrence in a certain year. In 2015, the area of forests in Slovakia reached 2.014 mil. ha. Within the 20 years (from 1998 to 2017), the total felling reached $162.52 \mathrm{mil}^{3} \mathrm{~m}^{3}$, out of this $47.99 \%$ were ascribed to a salvage felling. Abiotic agents were the most damaging agents $\left(42.28 \mathrm{mil}^{\mathrm{m}} \mathrm{m}^{3}\right.$ of damaged wood), out of it a wind was the most important one. Biotic damaging agents were the second important group (32.165 mil. $\mathrm{m}^{3}$ ), whereas bark beetles on spruce were the most important. The third group and the less damaging one was anthropogenic agents group $\left(3.555 \mathrm{mil}^{3} \mathrm{~m}^{3}\right)$ with an air pollution as the most important damaging agent. There was no statistically significant difference in the volume of processed trees within salvage felling caused by abiotic and biotic damaging agents. However, these two groups caused significantly higher damages than the third group of anthropogenic damaging agents. There were two major wind damages, Alžbeta in 2004 and Žofia in 2014 with damaged wood $5.3 \mathrm{mil} . \mathrm{m}^{3}$ and $5.2 \mathrm{mil} . \mathrm{m}^{3}$, respectively. They occurred in southern, central and northern part of Slovakia. As damaged wood was not processed from strict nature conservation areas, the secondary damaging agents, mostly Ips typographus on Norway spruce reproduced as much that after some years it cumulatively reached or even exceeded damages from those two major windthrows episodes.
\end{abstract}

Key words: Picea abies L. (Karst.); Pinus sylvestris L.; damaging agents; windstorms; bark beetles

\section{Introduction}

The forests in Slovakia cover about 2 mil. ha and that is over $40 \%$ of the total Slovak area. The European beech (Fagus sylvatica L.) is the most common forest tree species with its $33.2 \%$ coverage. Next forest tree species are Norway spruce (Picea abies L. (Karst.)), oaks (Quercus spp.), pines (Pinus spp.) and silver fir (Abies alba Mill.) with their coverage $23.4 \%, 10.6 \%, 6.8 \%$ and $4.1 \%$, respectively (Anonymous 2016).

During the last several decades, forests in Central Europe have been influenced by many impacts such as an industrialization, an air pollution (Crippa et al. 2015) and recently also by intensive climate changes (Hlásny et al. 2014). At the end of $80 \mathrm{~s}$ of $20^{\text {th }}$ century the political system in Slovakia as well as in neighboring countries, has changed and a management of not state forests, that were from the end of 40 s to the end of 80 s of 20 th century managed by state, have returned back the management of proper owners (Anonymous 2016). At the beginning of new millennium, there has been a strong pressure to increase the number of new nature conservation areas and limited forest management was stated in valuable ones. All these factors have regularly shaped the forest management with regard to minimize expenses (Anonymous 2016).

As forest ecosystems belong to the most natural ecosystems at least in Central Europe, they can show up more natural signs of this climatic change trends than 
other ecosystems (Zúbrik \& Kunca 2006; Santini et al. 2013). Due to a climate change as well as other disturbing factors the coverage of major tree species changed e.g. Norway spruce decreased from $26.3 \%$ in 2005 to $23.4 \%$ in 2015 and on the other hand a European beech coverage increased from 31.0 to $33.2 \%$. Changes in other forest tree species were far less dramatic within that short period (Anonymous 2016).

These are just several predisposing factors that may be taken into consideration in connection with largescale forest damage events in Slovakia as well as in many other European countries. The paper sums up the forest disturbance events which have occurred in Slovakia within the last 20 years (1998-2017).

\section{Methods}

The systematic records of forest damaging agents in Slovakia started in 1960 at the Forest Research Institute in Zvolen. At that time, an annual statistical form named L116 was created and it was in practice with just little adjustments up to 2011, when a new law on forest records has come into force (Kunca et al. 2014b). Statistical report L116 gradually upgraded some agents until 2011, when it turned into the law (Law No. 297/2011 Z. z. on forestry management records). So, finally, there were 56 damaging agents or damages in L116 report separated into three major groups:

A) abiotic -7 agents: a wind, a snow, a rime, a drought, a frost, a flooding, unknown abiotic agents,

B) biotic - 44 agents: Ips typographus L., Pityogenes chalcographus L., Scolytus intricatus Ratz., Tomicus minor Htg., Tomicus piniperda L., Ips sexdentatus Born., Ips acuminatus Gyll., Pityokteines curvidens Germ., Ips cembrae Heer., Xyloterus lineatus Ol., other bark beetles, Lymantria dispar L., Tortrix viridana L., Operphtera brumata L., Erannis defoliaria Cl., Bupalus piniaria L., Calliteara pudibunda L., Melolontha sp., Cephalcia abietis L., Pristiphora abietis Christ., Lymantria monacha L., Diprion pini L., Neodiprion sertifer Geoffr., Choristoneura murinnana Hübner, Dreyfusia nordmannianae Eckst., Rhyacionia buoliana (Denis \& Schiffermuller), Dendrolimus pini L., Sachiphantes viridis Ratz., Adelges laricis Vall., Coleophora laricella Hübner, Leucoma salicis L., Armillaria sp., Heterobasidion annosum Fr. (Bref.), rots, Ophiostoma sp., Lophodermium pinastri (Schrad.) Chevall., other needlecasts, cankers, rusts, mildews, unknown fungal diseases, games, rodents, weeds,

C) anthropogenic agents - 5 agents: an air pollution, a fire, a wood stealing, a grazing, an unknown anthropogenic agents.

Both, a statistical form L116 as well as the following statistical report set in law from 2011 were based on the volume of the total felling and the salvage felling which is considered as one of the main pointer of the forest health. A relative salvage felling, that is calculated as the volume of the salvage felling divided by the total felling and multiplied by 100 (to express it as a percentage), served as a mean to compare the annual salvage felling. The salvage felling had to be justified by damaging agents.

Foresters were obliged to fill up the annual statistical form L116 at the end of the year and pass it to the National Forest Centre - Forest Research Institute in Zvolen by 60 days after the end of the year. While some agents can be quite easily determined e.g. wind damages, others have to be proven by laboratory analyses e.g. air pollution.

Researchers summarized obtained data by the damaging agents, regions and tree species and results were published in the annual report on the occurrence of damaging agents in the last year with a short term prognosis for the next 5 years. The data come from the forest area that was 2.014 mil. ha in 2015 (Anonymous 2016). The report is distributed to all state district administrations, larger non-state subjects and major libraries. Altogether 300 publications have been distributed annually within the last 20 years.

The new law on forestry records has become effective in 2011, and salvage felling realized in 2012 was already evaluated by the new method. The major change of the damaging agent's records was that information came up from all forestry subjects, salvage felling was measured in less details and data were collected first by state district administrations and then centralized at the National Forest Centre in Zvolen. There were 48 agents, out of it there were 5 in the group of abiotic agents, 37 in the group of biotic agents and 6 in the group of anthropogenic agents.

In the results we merged damages caused by Ips typographus and Pityogenes chalcographus into a group Bark Beetles on Spruce and Tomicus spp. and Ips sexdentatus a Ips acuminatus as Bark beetles on Pines.

Data in the analyses were processed with just simple statistical methods of Microsoft Excel and STATISTICA program. The influence of parameters were set by ANOVA procedures, a statistical significance of variables was stated by Tuckey test.

The second source of information on the occurrence of damaging agents and disturbance events was a consultancy service for foresters provided by the National Forest Centre - Forest Research Institute Zvolen, settled at the Department of Forest Protection and Game Management. The service has been working since 1957 under different names, since 1994 it has been called the Forest Protection Service (Kunca et al. 2014b). Specialists on biotic, abiotic and anthropogenic agents have been involved in national and international research projects and the knowledge and experiences obtained in the research have been passed to foresters. If a major disturbance damaged the larger forest area, foresters have been obliged to send that information to both the state administration and to the Forest Protection Service spe- 
cialists. Foresters have to report the damaged volume, the area and the main damaged trees species. That is the main source of data about the sudden natural disturbances (Kunca et al. 2014b).

\section{Results}

\subsection{Salvage felling}

According to the Green report (Anonymous 2016), the current overall wood resources are estimated to be approximately $487.12 \mathrm{mil} . \mathrm{m}^{3}$, with the overall spruce resources $111.88 \mathrm{mil} . \mathrm{m}^{3}$. The total felling in Slovak forests reached 162.52 mil. $\mathrm{m}^{3}$ (Table 1 ) and that is $33.99 \%$ of the total resources. In ratio to the average total felling, its annual volume fluctuated between $68.09-125.40 \%$. Salvage felling reached 78.00 mil. $\mathrm{m}^{3}$ (Table 1 ), which is $47.99 \%$ of the total felling in 1998-2017. In this period, the annual salvage felling fluctuated in the range of $54.01-160.86 \%$ of the average salvage felling. There were 9 years when annual salvage felling exceeded average salvage felling (Fig. 1).

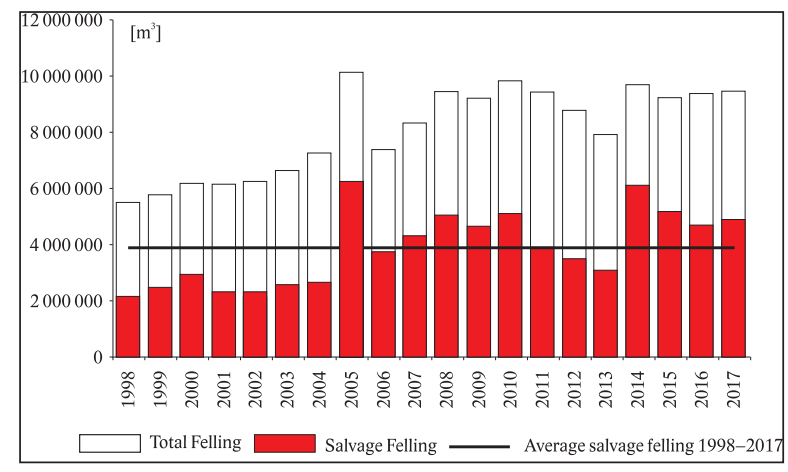

Fig. 1. Development of both total and salvage felling in the Slovak Republic over the period 1998-2017.

On November 19, 2004 windthrow Alžbeta damaged $5.3 \mathrm{mil} \mathrm{m}^{3}$. That was the estimation done by the organization responsible for monitoring forest resources and inventorying them (Lesoprojekt). Most of the damaged wood was processed in 2005, much less amount in 2006. Anyway, the damaged wood in strictly conservation areas could not be processed and under its bark the beetles easily several times reproduced. From 2007 the bark bee- tles from conservation areas started to infest standing trees and by 2010 sanitary felling was caused mostly by bark beetles in Norway spruce stands. The wet and cold weather in 2010 slowed down development of bark beetles and the amount of bark beetles damages went down. On May 15, 2014 windthrow Žofia damaged 5.2 mil. $\mathrm{m}^{3}$. As it occurred in May, most of the damaged wood was processed by the end of 2014 , the rest was processed by 2016. As it was after windthrow Alžbeta, the damaged wood in strictly conservation areas could not be processed and the bark beetles from unprocessed wood spread into standing healthy forests and in 2017 started to infest them.

\subsection{Damaging agents}

The salvage felling was caused by three major groups of damaging agents. Abiotic and biotic damaging agents largely dominated over anthropogenic damaging agents with proportion of $52.6 \%, 43.0 \%$ and $4.4 \%$, respectively. The biggest variation was performed within the abiotic damaging agents, the lowest with the anthropogenic damaging agents (Table 2). While the amount of processed wood damaged by anthropogenic damaging agents was gradually decreasing, the one damaged by abiotic damaging agents had 2 culmination peaks (in 2005 and 2014) and the one damaged by biotic agents culminated in 2009 and in 2017 was still rising up (Fig. 2).

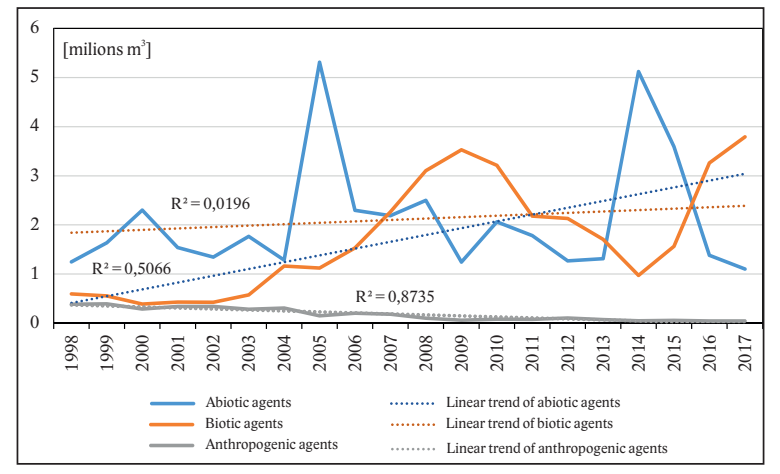

Fig. 2. Development of volume of processed wood from salvage felling caused by the three major groups of damaging agents.

There were statistically significant differences between averages of damaged wood caused by abiotic, biotic, and

Table 1. Volume of total felling and salvage felling in the Slovak Republic within the period 1998-2017.

\begin{tabular}{|c|c|c|c|c|c|}
\hline \multirow{2}{*}{ Felling } & Sum & Annual average & Standard deviation & Minimum & Maximum \\
\hline & \multicolumn{5}{|c|}{$\left[\right.$ mil. $\left.\mathrm{m}^{3}\right]$} \\
\hline Total felling & 162.52 & 8.13 & 1.57 & 5.53 & 10.19 \\
\hline Salvage felling & 78.00 & 3.90 & 1.32 & 2.11 & 6.27 \\
\hline Relative salvage felling [\%] & 47.99 & - & - & - & - \\
\hline
\end{tabular}

Table 2. Wood volume affected by major groups of damaging agents in the Slovak Republic forests within the period 1998-2017.

\begin{tabular}{|c|c|c|c|c|c|}
\hline \multirow{2}{*}{ Major groups of damaging agents } & Sum & Average & Standard deviation & Minimum & Maximum \\
\hline & \multicolumn{5}{|c|}{$\left[\mathrm{mil} . \mathrm{m}^{3}\right]$} \\
\hline Abiotic Pest Agents & 42.280 & $1.703 \mathrm{a}$ & 1.218 & 1.102 & 5.311 \\
\hline Biotic Pest Agents & 32.165 & $1.547 \mathrm{a}$ & 1.150 & 0.390 & 3.793 \\
\hline Anthropogenic Pest Agents & 3.555 & $0.128 \mathrm{~b}$ & 0.127 & 0.045 & 0.391 \\
\hline Total & 78.000 & - & - & - & - \\
\hline
\end{tabular}


anthropogenic damaging agents $(\mathrm{p}<0.01)$. By post-host tests, damages by anthropogenic damaging agents were significantly lower than damages by biotic or abiotic damaging agents $(p<0.01)$. However, there was no statistical difference between damages caused by abiotic and biotic damaging agents $(\mathrm{p}>0.05)$.

Wind caused significantly higher damages than the rest of abiotic damaging agents $(\mathrm{p}<0.01)$. Differences between other groups of abiotic damaging agents were not significant ( $p>0.05)$ (Table 3$)$.

As for biotic damaging agents, damages of bark beetles on spruce were significantly higher than damages caused by other biotic damaging agents $(p<0.01)$. Differences between other groups of biotic damaging agents were not significant ( $p>0.05)$ (Table 4).

Air pollution caused significantly higher damages than other anthropogenic damaging agents $(p<0.01)$. Differences between other anthropogenic damaging agents were not significant $(\mathrm{p}>0.05)$ (Table 5).

Within the 20-year long period, a wind was the most serious damaging factor (Table 3 ). The most serious windthrow occurred on November 19, 2004, and it got the name Alžbeta. By the professional estimation of the Lesoprojekt, state governmental organization, it damaged 5.3 mil. $\mathrm{m}^{3}$ of wood, mostly in Norway spruce forests of central and northern Slovakia (Kunca \& Zúbrik 2006). The second similarly damaging windthrow occurred on May 15, 2014. By the professional estimation of the National Forest Centre - Institute for Forest Resources and Information in Zvolen, it damaged 5.2 mil. $\mathrm{m}^{3}$ of Norway spruce forests of Central and southern Slovakia (Fig. 4). It got the name Žofia (Kunca et al. 2016). That amount of damaged wood covered not only managed forests, but also forests in conservated areas. At the state level that was not separated into these two categories (managed forests, conservation forests). Far less damaging windthrow occurred on June 22-23, 1999 in European beech forests of western Slovakia and on August 23, 2007 in Norway spruce forests of central Slovakia. Each of them damaged 1 mil. $\mathrm{m}^{3}$. These 4 windthrows represented for $33 \%$ of all windthrows during that time.

Bark beetles outbreak were represented by Ips typographus. The outbreak started in 20062 years after windthrow Alžbeta in the same regions as windthrows occurred (Fig. 5). It was caused because of strict forests nature conservation the damaged wood was not processed. In that wood bark beetles cumulated and suddenly spread into the surrounding forests.

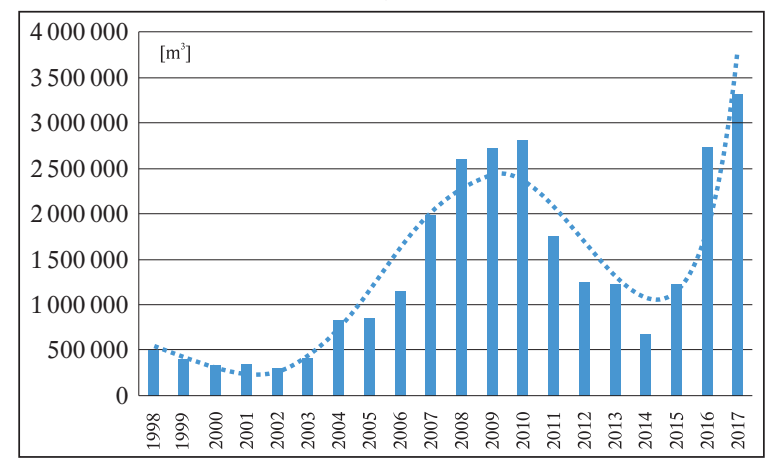

Fig. 3. Recorded volume of spruce wood infested by bark beetles in the Slovak Republic within the period 1998-2017.

By 2014 the situation with bark beetles has gradually stabilized, the salvage felling caused by bark beetles on

Table 3. Processed volume of wood from salvage felling due to selected abiotic damaging agents in the Slovak Republic forests within the period 1998-2017.

\begin{tabular}{lcccc}
\hline \multirow{2}{*}{ Major group of abiotic damaging agents } & Sum & Average & Standard deviation & Minimum \\
\cline { 2 - 5 } & & \multicolumn{3}{c}{ Maximum } \\
\hline Wind & 37.558 & $1.540 \mathrm{a}$ & 1.251 & 0.934 \\
Snow & 1.488 & $0.041 \mathrm{~b}$ & 0.099 & 0.5177 \\
Icing + Glaze & 0.638 & $0.004 \mathrm{~b}$ & 0.106 & 0.014 \\
Drought & 2.070 & $0.102 \mathrm{~b}$ & 0.030 & 0 \\
Other abiotic damaging agents & 0.510 & $0.016 \mathrm{~b}$ & 0.023 & 0.045 \\
\hline
\end{tabular}

Comment: Values in a column indicated by the same letter do not differ significantly.

Table 4. Processed volume of wood from salvage felling due to selected biotic damaging agents in the Slovak Republic forests within the period 1998-2017.

\begin{tabular}{|c|c|c|c|c|c|}
\hline \multirow{2}{*}{ Major group of damaging agents } & Sum & Average & Standard deviation & Minimum & Maximum \\
\hline & \multicolumn{5}{|c|}{ [mil. $\left.\mathrm{m}^{3}\right]$} \\
\hline Spruce wood infested by bark beetles & 27.588 & $1.187 \mathrm{a}$ & 0.990 & 0.321 & 3.319 \\
\hline Pine wood infested by bark beetles & 0.424 & $0.004 \mathrm{~b}$ & 0.031 & 0.001 & 0.089 \\
\hline Armillaria spp. & 2.873 & $0.128 \mathrm{~b}$ & 0.094 & 0.010 & 0.295 \\
\hline
\end{tabular}

Comment: Values in a column indicated by the same letter do not differ significantly.

Table 5. Processed volume of wood from salvage felling due to selected anthropogenic damaging agents in the Slovak Republic forests within the period 1998-2017.

\begin{tabular}{lcccc}
\hline \multirow{2}{*}{ Major group of damaging agents } & Sum & Average & Standard deviation & Minimum \\
\cline { 2 - 5 } & & & {$\left[\right.$ mil. $\left.^{3}\right]$} & \\
\hline Air pollution & 3133873 & $156694 \mathrm{a}$ & 122961 & 24969 \\
Fire & 109712 & $5486 \mathrm{~b}$ & 5576 & 354 \\
Wood stealing & 239075 & $11954 \mathrm{~b}$ & 5656 & 20736 \\
Other agents & 71996 & $3600 \mathrm{~b}$ & 3000 & 5127 \\
\hline
\end{tabular}

Comment: Values in a column indicated by the same letter do not differ significantly. 
Norway spruce decreased to $0.7 \mathrm{mil} . \mathrm{m}^{3}$. The windthrow Žofia in 2014 triggered the same process of bark beetles outbreak as occurred after 2004, and in 2017 the salvage felling caused by bark beetles on Norway spruce increased to 3.2 mil. $\mathrm{m}^{3}$ (Fig. 3).

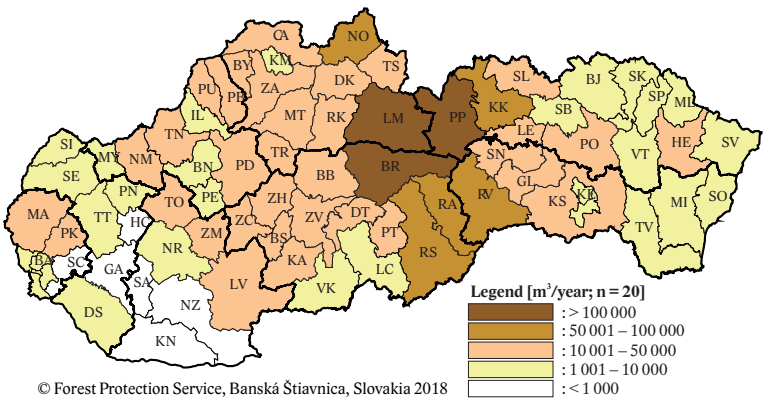

Fig. 4. Distribution of wood volume processed in the salvage felling caused by wind (average from years 1998-2017).

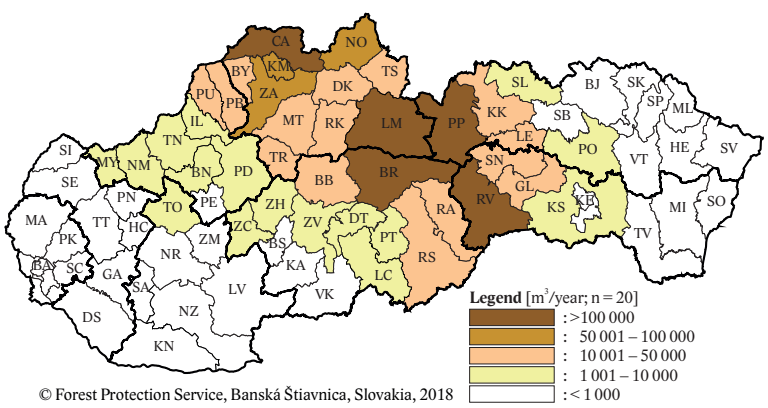

Fig. 5. Distribution of wood volume processed in the salvage felling caused by Ips typographus and Pityogenes chalcographus on spruce (average from years 1998-2017).

\section{Discussion}

The salvage felling belongs to tools for evaluating the forest health in some countries (Kolk et al. 2013; Kunca 2014; Knížek et al. 2015; Kärhä et al. 2018; Zahradník \& Zahradníková 2019). That felling is also known as a sanitary or a sanitation logging and is initiated by disturbances that could be separated into three main groups of abiotic, biotic and anthropogenic agents. Obviously, there are many agents within these groups. Some state administrations select the agents that are obligatorily monitored and their damages have to be annually reported from certain territory. Based on variable natural conditions in Europe, there are alike established variable divisions of Europe regions (Schelhaas et al. 2003; Spiecker 2003; Zúbrik et al. 2013). As that set of agents is not harmonized in European Union by some international authority, it usually differs from state to state or from region to region. While a fire belongs to the most important agents in the Mediterranean countries, windstorms play the most important role as primary agents in the Atlantic and Continental temperate zone of Europe (Spiecker 2003). Out of this, single monitored agents varies not only by territory but also in time. In Slovakia a number of monitored agents within 20 years changed from 56 in 1998 to 48 in 2012 (Kunca 2005; 2014). In spite of differences in number and set of monitored agents, a salvage felling must be caused by some of the abiotic, biotic or anthropogenic agents and these three major groups are harmonized at least in the European Union (Schelhaas et al. 2003; Spiecker 2003).

A relative salvage felling is an important parameter that is calculated in order to be able to compare salvage fellings in different regions. The salvage felling in Slovakia from 1998 to 2017 was caused by both, major and minor disturbances. The proportion of annual salvage felling on the total felling during 1998-2017 was as much as $47.99 \%$ (min. $33.7 \%$ max. $63.2 \%$ ), and that is 5.9 times more than European long term annual average of disturbances, that Schelhaas et al. (2003) calculated at the level of $8.1 \%$ over the years $1950-2000$. It should be taken into account that Schelhaas et al. (2003) measured just major disturbances, and neglected smaller damages. A salvage felling in neighboring mountainous countries was also quite variable and high. Knížek et al. (2015) states that salvage felling in the Czech Republic within those 10 years period varied between $20 \%$ (in 2012) and $75 \%$ (in 2007) with its average at 41\%. In Slovakia the salvage felling within 10 years period (2004-2013) was 53.2\% (Kunca et al. 2015) and it was higher level than during 20 years period (47.99\%). It is clear that longer period compensate short term fluctuation of any variable.

In spite of the high relative salvage felling or the proportion of major disturbances on total felling in Slovakia, major European disturbances did not reach Slovakia. The windstorm Vivian in 1990 damaged $120 \mathrm{mil}^{3} \mathrm{~m}^{3}$ in western Europe (König et al. 1995). At the end of 1999 there were three windstorms (namely Anatol, Lothar and Martin) that damaged $180 \mathrm{mil}^{3} \mathrm{~m}^{3}$ of wood in forests of different European regions (Sacre 2002). There was one of the biggest windstorms in Europe that occurred on January 8, 2005 in southern Sweden and Denmark and on January 9, 2005 in Estonia. It is known as Gudrun and only in southern Sweden it damaged $75 \mathrm{mil.} \mathrm{m}^{3}$ of wood (Schlyter et al. 2006; Langström et al. 2009). Recently, in 2017, there were two larger windstorms in western and central Europe. On August 11, 2017 the windstorm damaged more than $10 \mathrm{mil} . \mathrm{m}^{3}$ of wood in western Poland (Trebski 2017). On October 29, 2017 windstorm Herwart damaged wood in Germany as well as in the Czech republic where it is estimated that 2.5 mil. $\mathrm{m}^{3}$ were damaged (Lubojacký \& Knížek 2017).

None of them reached Slovakia except for windstorm Kyrill in 2007, but it is considered just as a minor windstorm disturbance in Slovakia with its only $0.4 \mathrm{mil}^{3} \mathrm{~m}^{3}$ of damaged wood. However, in Western Europe it damaged 55 mil. $\mathrm{m}^{3}$, predominantly in Germany and the Czech Republic (Kunca et al. 2014a). The directions of low pressure paths and storm damages in European region are demonstrated on maps by Gardiner et al. (2008; 
2011), at the regional level in Slovakia wind directions are described by Konôpka et al. (2008).

Short term analysis of damaging agents in Slovakia (1998-2017) points out that group of abiotic damaging agents were the most important factors influencing salvage felling (Table 2). From the specific damaging agent's point of view, the wind was the factor that damaged the biggest amount of wood (Table 5). The wind speed on November 19, 2004 (during windthrow Alžbeta) reached $140 \mathrm{~km} / \mathrm{h}$, in the gusts even $230 \mathrm{~km} / \mathrm{h}$. The wind speed on May 15, 2014 (during windthrow Žofia) went only $77 \mathrm{~km} / \mathrm{h}$, in gust $165 \mathrm{~km} / \mathrm{h}$, but damages were nearly the same as during windthrow Alžbeta. It happened because there were 2 weeks continuous rain and the soil was completely wet while in 2004 the soil was at least partially frozen.

The wind similarly participated on the salvage felling in the highest proportion in many Central European countries, as well as in other parts of Europe for the last several decades (Spiecker 2003; Schelhaas et al. 2003; Zach et al. 2008; Grodzki2010; Kolket al. 2013; Knížek et al. 2015). Schelhaas et al. (2003) stated that windstorms represent $53 \%$ of disturbances in Europe, while in Slovakia within $1998-2017$ it was just $48.15 \%$, so close to the European average.

Bark beetles on spruce (Ips typographus and Pityogenes chalcographus) were the second most important damaging agent in Slovakia. The bark beetles on spruce damaged $35.37 \%$ of total amount of salvage felling. It is long well-known that European spruce bark beetle is the secondary damaging agent and is often followed by windthrow and last decades driven also by climate change (Pfeffer \& Skuhravy 1995; Christiansen \& Bakke 1988; Blennow \& Olofsson 2008; Gardiner et al. 2008; Marini et al., 2013). Moreover, there are several examples that bark beetles on spruce following wind, fire, drought, snow or ice (Groot et al. 2018) was subsequently more dangerous pest than previous primary agents (Christiansen \& Bakke 1988; Kunca et al. 2011; Nikolov et al. 2014;). Catastrophic bark beetle outbreak after windstorms have occurred in the Czech republic in the Šumava Mountains after windstorms of 1868 and 1870 (Pfeffer \& Skuhravy 1995), in Sweden in 1969 (Nilsson et al. 2004) or recently in Sweden in 2005 or 2007 (Langström et al. 2009), in Lithuania (Zolubas \& Dagilius 2009) or in Far East Russia (Soukhovolsky 2009; Tarasova 2009). Windstorm Alžbeta from November 19, 2004 in Slovakia can be added to that list of examples. When Windstorm Alžbeta in 2004 damaged 5.3 mil. $\mathrm{m}^{3}$ (Koreň 2005; Kunca \& Zúbrik 2006), the broken and uprooted trees were not processed completely by the beginning of the growing season 2007. Slovak law on nature conservation prevented that kind of management of damaged wood, so secondary damaging agents, mainly European spruce bark beetle, started to multiply its population abundance (Kunca et al. 2011; Nikolov et al. 2014). According to Nikolov et al. (2014) broken and uprooted trees kept their bark attractiveness for colonization by bark beetles even 2 years after the windthrow. These two years bark beetles multiplied in that damaged wood and in spring 2007 all beetles swarmed and were searching for new trees in the surrounding standing trees. The bark beetles calamity started in a great amount. The attractive wood material for bark beetles was later supported by new damaged wood from the Snowfall Tamara in January 2006 and then from Windstorms Kyrill on January 9, 2007 and from Windstorm Filip on August 23, 2007. Their damages reached together $1.9 \mathrm{mil}^{3} \mathrm{~m}^{3}$ (Kunca et al. 2015). The culmination of the wood volume damaged by bark beetles was in 2010. That year was very wet and that could slow down the bark beetle development. Averaged annual precipitation per one meteorological station reached 1140 $\mathrm{mm}$ in 2010 (long-term average is $751 \mathrm{~mm}$ ) and that was the biggest amount since 1880 when precipitation started to be measured in Slovakia (Pecho et al. 2010; Zeleňáková et al. 2017).

The European spruce bark beetle outbreak afterwindstorms Alžbeta and Žofia were predicted by researchers (Zúbrik 2005; 2006) but that risk was not accepted by environmental state administrations as the primary factor for applying the management of damaged and surrounding forests. It was the nature protection that determined the forest management that finally resulted in large-scale European spruce bark beetle outbreak in the natural, semi natural and artificial monocultures of Norway spruce. This was the further example how difficult it is to harmonize nature conservation management with regards to forest functions, climate change scenarios and scientific knowledge about it all (Spiecker 2003; Zubizarreta-Gerendiain et al. 2017).

The global climate change concept expects the occurrence of weather extremes that will limit the life in the regions. So, a drought is supposed to be the most important stress factor influencing forests as well (Hlásny et al. 2014; Pešková et al. 2015). However, forests in Central Europe resist the drought as a prime damaging agent. However, it is a serious predisposing factor that weakens tree defense mechanisms against bark beetles as well as against Armillaria infection or other biotic damaging agents.

The structure of forest damaging agents is determined by several factors; one of them is a forest tree species composition. The biggest proportion of damaged wood volume in Slovakia occurred on Norway spruce. National ecological survey (Anonymous 2016) reports that Norway spruce originally grew on $4.9 \%$ of forest land instead of present $23.4 \%$. Due to windstorms and biotic damaging agents damages the Norway spruce coverage decreased from $26.3 \%$ in 2005 to $23.4 \%$ in 2015 (Anonymous 2016). Out of this, 18.5\% (372 th. ha) of Norway spruce has been growing on unsuitable sites and so they are highly predisposed to any damaging agents. That is very clear that Norway spruce damaging agents are more active than damaging agents of other 
forest trees, which proportion grown on unsuitable sites is much less (Anonymous, 2016). The artificial spread of Norway spruce in Slovak territory, as well as in other Central European countries, is a heritage from $19^{\text {th }}$ and $20^{\text {th }}$ century. At that time, planting forest trees was a state program and Norway spruce provided very valuable wood quality, although on the account of ecological stability of forests, which was not well known at that time. Anyway, since Norway spruce is under European conditions still economically extremely important tree species, it will be accepted in reasonable proportion in temperate zone in long-term prospect. However, this species must be managed with special attention to its specific threats, ergo implementing forest protection measures mitigating wind and bark beetle risks (Kunca et al. 2007; Konôpka \& Konôpka 2008).

\section{Conclusions}

Awind and bark beetles on Norway spruce were the most important damaging agents in Slovakia within two decades (1998-2017). It was evaluated by the salvage felling that was caused by forest harmful agents. The recent dramatic increase of forest damages caused by bark beetles relates to large-scale wind-break disasters. The damaged wood from those windthrows was not processed in time and completely because of restrictions of forest management in nature conservation areas. In general, Norway spruce is the most effected forest tree species. It is likely that Norway spruce proportion in Slovakia, as well as in Central European countries will decrease in the future due to climate change, biotic damaging agents and the nature protection preferences. New forests in the localities damaged by wind, snow or biotic damaging agents are established prevailingly with regards to suitable ecological conditions for trees and climate change scenarios and if possible, natural regeneration is preferred. These approaches in forest stand regeneration together with silvicultural and protection measures would gradually decrease amount of salvage felling in long-term prospect (Konôpka \& Konôpka 2011; Vakula et al. 2015).

\section{Acknowledgement}

The paper was supported by the Slovak Research and Development Agency based on the agreement No. APVV-0707-12, $A P V V$-14-0567, APVV-15-0348, APVV-15-0531, APVV-160031. The paper also represents the output of projects „Advanced technologies of trees protection of the juvenile growth stages " ITMS 26220220120, „Centre of Excellence for Biological Methods of Forest Protection" ITMS 26220120008 and "Use of the bio-plant Repelak based on ecologically effective natural substances against damage of forest tree species by the game"ITMS: 26220220025.

\section{References}

Anonymous, 2016: Správa o lesnom hospodárstvev Slovenskej republike za rok 2015 -Zelená správa (Report on the Status of Forestry in the Slovak republic of 2015 - Green Report). Bratislava, Ministerstvo pôdohospodárstva a rozvoja vidieka Slovenskej republiky, $76 \mathrm{p}$.

Blennow, K., Olofsson, E., 2008: The probability of wind damage in forestry under a changed wind climate. Climatic Change, 87:347-360.

Christiansen, E., Bakke, A., 1988: The spruce bark beetle of Eurasia. In: Berryman, A. A. (ed.): Dynamics of Forest Insects Populations. Patterns, Causes, Implications. New York and London, Plenum Press, p. 479-503.

Crippa, M., Janssens-Maenhout, G., Dentener, F., Guizzardi, D., Sindelarova, K., Muntean, M. et al., 2016: Forty years of improvements in European air quality: the role of EU policy-industry interplay. Atmospheric Chemistry and Physics, 16:3825-3841.

Gardiner, B., Blennow, K., Carnus, J.-M., Fleischer, P., Ingemarson, F., Landmann, G. et al., 2011: Destructive Storms in European Forests: Past and Forthcoming Impacts. Final report to European Commission - DG Environment, European Forest Institute, Atlantic European Regional Office-EFIATLANTIC, $138 \mathrm{p}$.

Gardiner, B., Byrne, K., Hale, S., Kamimura, K., Mitchell, S.J., Peltola, H. et al., 2008: A review of mechanistic modelling of wind damage risk to forests. Forestry, 81:447-463.

Grodzki, W., 2010: The decline of Norway spruce Picea abies (L.) Karst. stands in Beskid Slaski and Živiecki: theoretical concept and reality. Beskydy, 3:19-26.

Groot, M. de, Ogris, N., Kobler, A., 2018: The effects of a large-scale ice storm event on the drivers of bark beetle outbreaks and associated management practices. Forest Ecology and Management, 408:195-201.

Hlásny, T., Mátyás, C., Seidl, R., Kulla, L., Merganičová, K., Trombík, J. et al., 2014: Climate change increases the drought risk in Central European forests: What are the options for adaptation? Lesnícky časopis Forestry Journal, 60:5-18.

Kärhä, K., Anttonen, T., Poikela, A., Palander, T., Laurén, A., Peltola, H. et al., 2018: Evaluation of Salvage Logging Productivity and Costs in windthrown Norway Spruce-Dominated Forests. Forests, 9, 280; doi:10.3390/f9050280.

Knížek, M., Liška, J., Modlinger, R. (eds.), 2015: Výskyt lesních škodlivých činitelů v roce 2014 a jejich očekávaný stav v roce 2015. Zpravodaj ochrany lesa. Supplementum. Praha, Výzkumný ústav lesního hospodářství a myslivosti, 78 p. 
Kolk, A., Grodzki, W., Jablonski, T., Jaworski, T., Malecka, M., Plewa, R. et al., 2013: Krótkoterminowa prognoza wystepowania wazniejszych szkodników i chorob infekcyjnych drzew lesnych w Polsce w 2013 roku. Instytute Badawczy Lesnictwa, Sekocin Stary, 173 p.

König, A., Mösmer, R., Bäumler, A., 1995: Silvicultural documentation of the planar storm damages in winter 1990 in Bavaria and meteorological conditions at the time of damage. LWF. Berichte aus der Bayerischen Landesanstalt fürWald und Forstwirtschaft 2, 352 p.

Konôpka, J., Konôpka, B., 2008: Koncept stratégie ochrany lesa proti hlavným druhom abiotických škodlivých činitel'ov. Lesnícky časopis - Forestry Journal, 54:193-212.

Konôpka, J., Konôpka, B., 2011: Koncepcia d'alšieho výskumu ochrany lesa na Slovensku so zretel'om na biologickýboj proti škodcom. Lesnícky časopis-Forestry Journal, 57:197-207.

Konôpka, J., Konôpka, B., Raši, R., Nikolov, Ch., 2008: Nebezpečné smery vetra na Slovensku. Lesnícke štúdie 60, Zvolen, NLC, 81 p.

Koreň, M., 2005: Vetrová kalamita 19. novembra $2004-$ nové pohl'ady a konsequencie. Tatry, p. 7-29.

Kunca, A. (ed.), 2005: Výskyt škodlivých činitel'ov v lesoch Slovenska za rok 2004 a ich prognóza na rok 2005. Zvolen, LVU Zvolen, 92 p.

Kunca, A., Zúbrik, M., 2006: Vetrová kalamita z 19. novembra 2004. Zvolen, NLC, 40 p.

Kunca, A., Zúbrik, M., Novotný, J., Gubka,A., Konôpka, B., Konôpka, J. et al., 2007: Škodlivé činitele lesných drevín a ochrana pred nimi. Zvolen, NLC, 208 p.

Kunca, A., Nikolov, Ch., Vakula, J., Leontovyč, R., Galko, J., Zúbrik, M., 2011: Vplyv aktívnej a pasívnej ochrany na šírenie kalamity sekundárnych škodlivých činitel'ov. Zvolen, NLC, 42 p.

Kunca, A. (ed.), 2014: Výskyt škodlivých činitel'ov v lesoch Slovenska za rok 2013 a ich prognóza na rok 2014. Zvolen, NLC - LVU Zvolen, 89 p.

Kunca, A., Galko, J., Zúbrik, M., 2014a:Významné kalamity v lesoch Slovenska za posledných 50 rokov. In: Kunca, A. (ed.): Aktuálne problémy v ochrane lesa 2014, Zborník referátov z 23. medzinárodnej konferencie konanej 23.-24.4.2014 v Kongresovom centre Kúpel'ov Nový Smokovec, Zvolen, NLC, p. 25-31.

Kunca, A., Nikolov, Ch., Zúbrik, M., Varínsky, J., Galko, J., Vakula, J. et al., 2014b: Lesnícka ochranárska služba a jej prezentácia na internete. In: Kunca, A. (ed.): Aktuálne problémy v ochrane lesa 2014, Zborník referátov z 23. medzinárodnej konferencie konanej 23.-24.4.2014 v Kongresovom centre Kúpel'ov Nový Smokovec, Zvolen, NLC, p. 5-7.

Kunca, A., Zúbrik, M., Galko, J., Vakula, J., Leontovyč, R., Konôpka, B. et al., 2015: Salvage felling in the Slovak forests in the period 2004-2013. Lesnícky časopis - Forestry Journal, 61:188-195.
Kunca, A., Zúbrik, M., Vakula, J., Galko, J., Konôpka, B., Leontovyč, R. et al., 2016: Výskyt škodlivých činitel'ov v lesoch Slovenska v rokoch 1960-2014, v roku 2015 a prognóza ich vývoja. Zvolen, NLC-LVU Zvolen, $139 \mathrm{p}$.

Langström, B., Lindelöw, A., Schroeder, M., Björklund, N., Öhrn, P., 2009: The spruce bark beetle outbreak in Sweden following the January-storms in 2005 and 2007. In: Kunca, A. \& Zúbrik, M., (ed.): Insects and Fungi in Storm Areas, Proceedings of the IUFRO Working Party 7.03.10 Methodology of Forest Insect and Disease Survey in Central Europe from the workshop that took place on September 15 to 19, 2008 in Štrbské Pleso, Zvolen, NLC - LVU Zvolen, p. 13-19.

Lubojacký, J., Knížek, M., 2017: Nebezpečí další eskalace kalamitní kůrovcové situace. Lesnická práce, 96:62.

Marini, L., Lindelöw, A., Jönsson, A. M., Wulf, S., Schroeder, L. M., 2013: Population dynamics of the spruce bark beetle: a long-term study. Oikos, 122:1768-1776.

Nikolov, Ch., Konôpka B., Kajba, M., Galko, J., Kunca, A., Janský, L., 2014: Post-disaster Forest Management and Bark Beetle Outbreak in Tatra Mountain Park, Slovakia. Mountain Research and Development, 34:326-335.

Nilsson, C., Stjernquist, I., Bärring, L., Schlyter, P., Jönsson, A. M., Samuelsson, H., 2004: Recorded storm damage in Swedish forests 1901-2000. Forest Ecology and Management, 199:165-173.

Pecho, J., Faško, P., Lapin, M., Kajaba, P., Mikulová, K., Štastný, P., 2010: Extrémne atmosférické zrážky na jar a na začiatku leta 2010 na Slovensku. Meteorologický časopis, 13:69-80.

Pešková, V., Lorenc, F., Modlinger, R., Pokorná, V., 2015: Impact of drought and stand edge on mycorrhizal density on the fine roots of Norway spruce. Annals of Forest Research, 58:245-257.

Pfeffer, A., Skuhravy, V., 1995: Der Buchdrucker Ips typographus L. (Col., Scolytidae) und seine Problematik in der Tschechischen Republik. Anzeiger für Schadlingskunde, Pfanzenschutz, Umweltschutz, 68:151-152.

Sacre, C., 2002: Extreme wind speed in France: the '99 storms and their consequences. Journal of Wind Engineering \& Industrial Aerodynamics, 90:11631171.

Santini, A., Ghelardini, L., De Pace, C., Desprez-Loustau, M. L., Capretti, P. Chandelier, A. et al., 2013: Biogeographical patterns and determinants of invasion by forest pathogens in Europe. New Phytologist, 197:238-250.

Schelhaas, M. J., Nabuurs, G. J., Schuck, A., 2003: Natural disturbances in the European forests in the $19^{\text {th }}$ and $20^{\text {th }}$ centuries. Global Change Biology, 9:1620-1633. 
Schlyter, P., Stjernquist, I., Bärring, L., Jönsson, A. M., Nilsson, C., 2006: Assessment of the impacts of climate change and weather extremes on boreal forests in northern Europe, focusing on Norway spruce. Climate Research, 31:75-84.

Soukhovolsky, V., 2009: Insects-xylophages in Sayana mountain forests after windthrow: population dynamics models. In: Kunca, A. \& Zúbrik, M., (eds.): Insects and Fungi in Storm Areas, Proceedings of the IUFRO Working Party 7.03.10 Methodology of Forest Insect and Disease Survey in Central Europe from the workshop that took place on September 15 to 19, 2008 in Štrbské Pleso, Zvolen, NLC - LVU Zvolen, p. 20-22.

Spiecker, H., 2003: Silvicultural management in maintaining biodiversity and resistance of forests in Europe - temperate zone. Journal of environmental Management, 67:55-65.

Tarasova, O., 2009: Regulatories of insect attacks of conifer trees after windthrow in forest stands in Sayana mountains (middle Siberie). In: Kunca, A. \& Zúbrik, M., (eds.): Insects and Fungi in Storm Areas, Proceedings of the IUFRO Working Party 7.03.10 Methodology of Forest Insect and Disease Survey in Central Europe from the workshop that took place on September 15 to 19, 2008 in Štrbské Pleso, Zvolen, NLC - LVU Zvolen, p. 34-35.

Trebski, K., 2017: Největší kalamita v historii státních lesů Polska. Lesnická práce, 96:577.

Vakula, J., Zúbrik, M., Kunca, M., Dubec, M., Find'o, S., Galko, J. et al., 2015: Nové metódy ochrany lesa. Zvolen, NLC, 292 p.

Zach, P., Kršiak, B., Kulfan, J., 2008: Vetrové kalamity v smrekových lesoch a premnoženia lykožrúta smrekového Ips typographus. E-ekológia lesa, odborné ekologické publikácie 2, Zvolen, SAV, 15 p.
Zahradník, P., Zahradníková, M., 2019: Salvage felling in the Czech Republic's forests during the last twenty years. Cent. Eur. For. J., 65:12-20.

Zeleňáková, M., Vido, J., Portela, M. M., Purc, P., Blištán, P., Hlavatá, H. et al., 2017: Precipitation trends over Slovakia in the period 1981-2013. Water, 9:922.

Zolubas, P., Dagilius, R., 2009: Small scale conservation status in forests - source of bark beetle problems? In: Kunca, A. \& Zúbrik, M., (eds.): Insects and Fungi in Storm Areas, Proceedings of the IUFRO Working Party 7.03.10 Methodology of Forest Insect and Disease Survey in Central Europe from the workshop that took place on September 15 to 19, 2008 in Štrbské Pleso, Zvolen, NLC-LVU Zvolen, p. 36-38. Zubizarreta-Gerendiain, A., Pukkala, T., Peltola, H., 2017: Effects of wind damage on the optimal management of boreal forests under current and changing climatic conditions. Canadian Journal of Forest Research, 47:246-256.

Zúbrik, M. (ed.), 2005: Projekt ochrany lesa na území ŠL TANAP-u po vetrovej kalamite zo dňa 19.11. 2004 - realizačný projekt pre rok 2005. Zvolen, LVÚ Zvolen, $85 \mathrm{p}$.

Zúbrik, M. (ed.), 2006: Projekt ochrany lesa - realizačný projekt pre rok 2006. Zvolen, NLC, 140 p.

Zúbrik, M., Kunca, A., 2006: Invasive and quarantine pests in forests in Slovakia. OEPP/EPPO Bulletin, 36:402-408.

Zúbrik, M., Kunca, A., Csóka, G., Forster, B., Hâruța, O., Hoch, G. et al., 2013: Insects and diseases damaging trees and shrubs of Europe. N.A.P. Editions, 535 p. 